\title{
О воспроизводстве арктического гольца в водоемах бассейна озера Имандра
}

\section{Королева И.М., Терентьев П.М., Зубова Е.М.}

Институт проблем промьииленной экологии Севера КНЦ РАН, Anamumbl, koririn@yandex.ru, pterentjev@mail.ru,seelewolf84@yandex.ru

Аннотация. Прослежены изменения состава ихтиофауны малых озер Хибинского горного массива от допромышленного периода по настоящее время. Исследованы особенности биологии, естественного воспроизводства арктического гольца Salvelinus alpinus L. в озерах Малый и Большой Вудъявр. В первом из них, где обитает мелкая форма гольца, икрометание происходит в октябре. Абсолютная плодовитость для самок этой популяции - 420 икринок. У гольцов из крупных озер этот показатель варьирует в среднем от 1.600 до 2.400 икринок. На основании высокой доли нерестящихся или готовых к нересту особей с сентября по октябрь, высказывается предположение о ежегодном нересте гольцов в данной популяции. В оз. Большой Вудъявр по данным 1930 г. наблюдался нерест гольца, который в последующих исследованиях, начиная с 2006 г, ни разу не отмечался. Вероятно, поддержание численности гольца в нем происходит за счет ската рыб из оз. Малый Вудъявр. В перспективе создания центра подготовки дайверов на оз. Мал. Вудъявр и возможного риска утраты популяции гольца предлагаются меры по обеспечению ее сохранения.

Ключевые слова: Хибины, арктический голец, малые озера, воспроизводство, плодовитость, подготовка дайверов, Субарктика.

\section{Reproductive success of the Arctic charr in small lakes of the Imandra Lake basin}

\author{
Koroleva I.M., Terentjev P.M., Zubova E.M. \\ Institute of the North Industrial Ecology Problems of Kola Science Centre, Apatity, koririn@yandex.ru, \\ pterentjev@mail.ru,seelewolf84@yandex.ru
}

\begin{abstract}
The results of long-term observations of changes in the composition of the fish community in small lakes in the Khibiny Mountains are presented. The study has been carried in Lakes Bolshoy and Malyy Vudjavr. The biological characteristics, reproduction of the Arctic charr Salvelinus alpinus L. were monitored through a long-term study (from 2006 to 2019) of two subarctic lakes. A small (dwarf) charr form lives in Lake Malyy Vudjavr. Spawning takes place here in October. Absolute fecundity for females of this population is 420 eggs, which is 5-6 times lower than the ones to large form. Based on the high proportion of spawning fish, we suggest that fish spawn annually. In Lake Bolshoy Vudjavr, we have never observed spawning. It is assumed that the abundance of charr in it occurs due to the migration of fish from Lake Malyy Vudjavr. Establishment of a divers training center carries the risk of loss of char population. Measures to conserve this population are proposed.
\end{abstract}

Key words: Khibiny, Arctic charr, small lakes, reproduction, fecundity, diver training, Subarctic.

Арктический голец это сложный комплекс экологических форм разной степени обособленности, вплоть до признания этих форм самостоятельными видами. Предметом наших исследований являлись пресноводные озерные гольцы, обитающие в водоемах Хибинского горного массива бассейна озера Имандра. Первые сведения об имандровских гольцах приводятся Ф.В. Крогиус (1926). В составе ихтиофауны озера они указаны как Salvelinus alpinus var salvelinus L. На основе анализа собственных данных по морфологии и остеологии, Колюшев А.И. отнес гольцов и палий Кольского полуострова к политипическому виду S. alpines и назвал их Salvelinus alpines lepechini (Gmelin) (Рыбы Мурманской области, 1966), там же была подтверждена целесообразность сохранения для него номенклатурного статуса в качестве подвида. В дальнейшем было принято озерного гольца водоемов бассейна оз. Имандра считать принадлежащим к S. alpinus complex и именовать как Salvelinus alpinus alpinus (L.) (Моисеенко и др., 2002). При этом отметим, что в Атласе пресноводных рыб России (2003) по-прежнему указывается, что в крупных озерах Кольского полуострова (Имандра, Умбозеро, Ловозеро) обитает палия Salvelinus lepechini (Gmelin, 1788). В материалах комплексных 
общих лимнологических исследований 1930 г., рыбы, обитающие в оз. Большой Вудъявр, именуются как палии, особо отмечается их яркая брачная окраска (Паллон, 1940).

Арктический голец населяет многие озера и реки Мурманской области (Берг, 1948; Ихтиофауна..., 2005). Наряду с семгой, кумжей, сигами относился к наиболее ценным для промысла видам, несмотря на сравнительно невысокую долю в уловах. В середине XX века произошло сокращение численности гольца в интенсивно облавливаемых водоемах озерно-речной системы р. Пиренга (Lukin, 2013). В Имандре депрессивному состоянию запасов гольца, помимо перелова, способствовали загрязнение акватории промышленными стоками. Определенный вклад внесла деятельность Кольской АЭС, приведшая к изменению термического режима, что негативно сказалось на миграциях холодолюбивого гольца, и потере части нерестилищ и кормовых угодий по причине осушения мелководий. Настоятельно рекомендовалось «безотлагательно разработать методику искусственного воспроизводства этих ценных рыб...и значительно увеличить их запасы в Имандре и Умбозере» (Рыбы..., 1966). Основой рыбоводных работ могли бы стать исследования Колюшева А.И. (1973), подробно изучившего особенности созревания половых желез, состава овоцитов и плодовитости гольцов и палий крупных озер Кольского полуострова - Имандра и Умбозеро. Отмечалось, что имея низкую плодовитость, голец не в состоянии компенсировать элиминацию части популяции за счет естественного воспроизводства. В настоящее время в Имандре и Пиренгских озерах голец встречается значительно реже, что подтверждается собственными контрольными обловами и опросными данными рыбаков-любителей.

В водоемах Хибинского горного массива, расположенных в бассейне Имандры, голец является важнейшим компонентом ихтиофауны. Вследствие незначительных размеров, водоемы никогда не имели промыслового значения, и представляют интерес для ихтиологических исследований с одной стороны, как типичные озера для горных областей Хибинского массива, с другой как объекты мониторинга влияния загрязнения от предприятий добычи и переработки апатит-нефелинового сырья. Озера соединяются порожистыми речками и имеют общий сток через р. Большая Белая, вытекающую из оз. Большой Вудъявр (Б. Вудъявр) (площадь озера 3.61 км²$^{2}$ и впадающую в оз. Имандра. Можно предположить, что водоемы заселены генетически однородными популяциями и наблюдающиеся различия объясняются экологическими условиями конкретного местообитания.

В оз. Б. Вудъявр в 1930-х гг. прошлого столетия голец (палия) являлся вторым по численности видом после сига. Встречались преимущественно мелкие особи, но известны случаи поимки экземпляров до 2.5 кг. Нерест происходил в первой декаде октября, по натурным наблюдениям икрометание осуществлялось в воронках родников, об окончании процесса можно было судить по появлявшимся на дне воронки небольшим удлиненным буграм. Температура воды в родниках колебалась в пределах $2.5-3.5^{\circ} \mathrm{C}$. Для оз. Б. Вудъявр рассматривалась возможность вселения ряпушки, как кормового объекта для гольца и кумжи, с целью увеличения их численности и дальнейшей организации спортивной рыбалки. Наличие непромерзающих речек позволило бы построить опытный рыбоводный завод для разведения гольцов (палий) и кумжи. После запуска обогатительной фабрики со спуском флотационных вод оз. Б. Вудъявр было обезрыблено. В оз. Малый Вудъявр (М. Вудъявр) (площадь озера $1.55 \mathrm{kм}^{2}$ ) были обнаружены кумжа и палия, последняя численно преобладала (Паллон, 1940).

Повторные ихтиологические исследования на этой группе озер были возобновлены в 2005 г. Собственные наблюдения показали, что в оз. Б. Вудъявр в период с 2005 по 2007 гг. голец являлся монодоминантом. После самопроизвольного вселения европейской корюшки (первые сведения о ее появлении датируются 2013 годом), доля гольца (по массе) снизилась до 54 \%. Начиная с 2015 г. в контрольных уловах стали регистрироваться кумжа и девятииглая колюшка. Основу уловов дают мелкие особи массой от 150 до 250 г, единично попадаются рыбы массой более 0.5 кг (примерно $10 \%$ ). Несмотря на близкие к датам 1930 г. сроки наблюдений (сентябрь - октябрь), готовые к нересту или уже отнерестившиеся особи в уловах отсутствовали. Единственным исключением стала пойманная 10 октября 2019 г. самка с гонадами IV стадии развития. Абсолютная плодовитость этой самки массой более килограмма равнялась 2870 штук икринок. 
В оз. М. Вудъявр в сетных уловах присутствовал исключительно голец, в его желудках встречалась девятииглая колюшка (Королева, Постнова, 2008). В 2019 г. в озере был пойман один экземпляр налима. Арктический голец представлен здесь мелкой (карликовой) формой. Длина тела по Смиту изменялась от 9.2 до $26.3 \mathrm{~cm}$, среднее значение $15.2 \mathrm{~cm}$. В уловах доминировали особи с длиной тела 13-16 см. Вес гольцов колебался в пределах 5-293 г, преобладали особи массой от 20 до 100 г.

Вудъяврские гольцы, вероятно, не смогут при необходимости послужить основой маточного стада для искусственного воспроизводства и зарыбления водоемов по причине их малочисленности. Хотя, имея приоритетом сохранение уникального местного генофонда, эту возможность не следует сбрасывать со счетов. Кроме того, при практически полном отсутствии современных сведений о воспроизводстве озерного гольца в этом регионе, представляется целесообразным опубликовать имеющиеся данные.

Гольцы, как и другие представители рода Salvelinus, являются полицикличными рыбами с единовременным осенним нерестом. Визуально пол у них можно определить в конце 2-го года жизни $(1+)$, когда происходит переход овоцитов на ранние ступени периода плазматического роста (I стадия зрелости половых желез). Характерной особенностью полового цикла является сохранение на протяжении всего жизненного цикла рыбы асинхронности роста овоцитов.

В крупных озерах гольцы становятся половозрелыми в четырехлетнем возрасте при длине тела около 30 см и массе около 400 г (Рыбы..., 1966). В оз. М. Вудъявр гольцы нерестились при значительно меньших размерах. У самцов масса в среднем составляла 43 г при длине АC 14.6 см, минимальные показатели - 20 г и 12 см. Средний вес самок был вдвое выше, чем у самцов и равен 85 г, по средней длине различия не так велики -18 см. Минимальные размеры готовой к икрометанию самки составили 31 г при длине 14.4 см. В соотношении полов, обычно доминируют самцы (таблица).

Таблица Соотношение нерестящихся и пропускающих нерест гольцов в оз. Малый Вудъявр, экз. (\%).

Table. The ratio of spawning and spawning loaches in Lake Malyy Vud'javr, n (\%).

\begin{tabular}{|c|c|c|c|c|}
\hline \multirow{2}{*}{ Период } & \multicolumn{2}{|c|}{ Самки } & \multicolumn{2}{c|}{ Самцы } \\
\cline { 2 - 5 } & $\begin{array}{c}\text { Незрелые или } \\
\text { пропускающие }\end{array}$ & Нерестовые & $\begin{array}{c}\text { Незрелые или } \\
\text { пропускающие }\end{array}$ & Нерестовые \\
\hline 29.09 .2006 & $14(14)$ & $17(16)$ & $1(1)$ & $70(68)$ \\
\hline 23.10 .2015 & $13(34)$ & $8(21)$ & $6(16)$ & $11(29)$ \\
\hline 10.10 .2019 & $2(10)$ & $4(21)$ & $3(16)$ & $10(53)$ \\
\hline Всего экз. & 29 & 29 & 10 & 91 \\
\hline
\end{tabular}

Нерест у гольцов в крупных озерах происходит в сентябре и при оптимальных условиях продолжается 2-2.5 недели. Для горных озер процесс размножения сдвигается на середину осени. В 2015 г. мы наблюдали текучих особей в последней декаде октября. Данный феномен объясняется аномально теплой для региона погодой, температура воздуха сохранялась на уровне $+5^{\circ} \mathrm{C}$. Весьма вероятно, что в оз. М. Вудъявр гольцы нерестятся ежегодно, о чем свидетельствует практически полное отсутствие в уловах особей, достигших типичных для данной популяции необходимых для созревания размеров, с гонадами на II, II-III стадиях развития в период нереста.

Обитание в суровых условиях субарктики, при коротком вегетационном периоде и низких температурах воды, у многих лососевых рыб приводит к сравнительно небольшой индивидуальной плодовитости гольцов (палий). Средний диаметр икринок старшей генерации у гольцов озер Кольского полуострова перед нерестом (IV-V стадия зрелости) колеблется от 4.3 до 5.0 мм, близкие величины мы получили и для гольца оз. М. Вудъявр - 3.4-4.3 мм. Для гольца оз. Умбозеро средняя плодовитость равнялась 1600 икр., для имандровского гольца указывались средние величины от 1940 до 2400 икринок. Количество икринок с возрастом и ростом рыб увеличивалось от 955 до 8045 шт. (Колюшев, 1973; Моисеенко и др., 2002). У самок гольца из оз. М. Вудъявр абсолютная 
плодовитость в среднем составила 420 икринок с колебаниями от 194 до 763 икринок. Эту величину следует признать крайне малой и свидетельствующей о высокой уязвимости популяции к изъятию рыбы.

Остается открытым вопрос о сроках нереста, структуре нерестового стада, плодовитости гольца из оз. Б. Вудъявр. Преобладание в нем некрупных особей на протяжении всего периода наблюдений подтверждает предположение, что оз. М. Вудъявр является основным водоемом, позволяющим за счет ската рыбы через р. Вудьяврйок постоянно пополнять и поддерживать популяцию гольца оз. Б. Вудъявр (Терентьев, 2008).

Учитывая полученные результаты, следует привлечь внимание государственных органов и общественности, к необходимости принятия незамедлительных мер к сохранению популяции арктического гольца в оз. М. Вудъявр. В рамках проекта «Подводная география Кольского полуострова» планируются подводные исследования наиболее перспективных мест объектов научнопросветительского туризма. Первым на очереди стоит оз. М. Вудъявр. С 2019 г. на нем уже проводится фестиваль подводных профессий «Погружение в Арктику». В перспективе - создание в Хибинах центра подготовки дайверов, с тренировками, как в бассейне, так и на самом озере (Соколов, 2019). В планах Центра арктических компетенций - работа не только с водолазами-профессионалами, но и организация обучения дайверовов-любителей, что приведет к круглогодичной антропогенной нагрузке на водоем. Несомненно, что наличие тренировочной площадки для погружения будет служить источником беспокойства и стресса для рыб, не исследовано влияние попадания загрязняющих веществ, смываемых с оборудования, на качество воды. В условиях очень ограниченной акватории и небольшого объема воды в озере, это может стать значимым и ощутимым негативным фактором для гидробионтов. Но, принимая во внимание локальное расположение площадки, главную опасность будет представлять неконтролируемый вылов гольца. Известно, что браконьерский облов озера как сетями, так и на удочку всегда имел место, но в свете создания центра подготовки дайверов, естественно ожидать развития инфраструктуры и увеличение числа туристов. Возрастающий антропогенный пресс может оказаться катастрофическим для рыбного населения обоих озер Б. Вудъявр и М. Вудъявр.

Вместе с тем, цивилизованный подход к хозяйствованию, основанный на всеобщем осознании необходимости сохранения этого уникального водоема, способен реально обеспечить его защиту. Строгий и действенный контроль, при наличии постоянного персонала на водоеме, за соблюдением запрета на вылов гольца, сохранение в чистоте берегов озера, эффективная система очистки неизбежных хозяйственно-бытовых стоков - вот некоторые меры, позволяющие обеспечить его привлекательность в целях научно-просветительского туризма в Хибинах.

В этой связи разработка мер по сохранению репродукционного потенциала гольцов и сведения к минимуму экологического ущерба становится одним из главных направлений природоохранной деятельности. Представляется уместным возвращение к обозначенной в 1930-х гг. задаче - обеспечения искусственного воспроизводства гольцов озер Б. Вудъявр и М. Вудъявр на основе создания небольшого по объемам рыбоводного предприятия. С учетом всё возрастающего запроса на спортивное рыболовство это может быть очень перспективно.

Работа выполнена в рамках темы НИР № 0226-2019-0045 (полевые работы на озерах Б. и М. Вудъявр) и частично поддержана из средств гранта РФФИ 18-05-60125 Арктика (интерпретация результатов по оз. М. Вудъявр) и РНФ № 19-77-10007 (интерпретация результатов по оз. Б. Вудъявр).

\section{Литература}

1. Атлас пресноводных рыб России в 2-х томах. Изд-во: Наука. 2003. Т. 1. 379 с.

2. Берг Л.С. Рыбы пресных вод СССР и сопредельных стран. Л. Изд-во: АН СССР. 1948. Т. 1. 466 с.

3. Ихтиофауна малых озер и рек Восточного Мурмана: биология, экология, ресурсы. Апатиты. Изд-во: КНЦ РАН. 2005. 264 c.

4. Колюшев А.И. Материалы по созреванию проходных гольцов и палий (p. Salvelinus) озер Имандра и Умбозеро // Вопр. ихтиологии. 1973. Т. 13. Вып. 4 (81). С. 633-645. 
5. Королева И.М., Постнова С.В. Морфологические показатели и особенности питания гольца озерно-речной системы реки Белая (Кольский полуостров) // Матер. Всерос конф. с междунар. участием «Экологические проблемы северных регионов и пути их решения». Апатиты. Изд-во: КНЦ РАН. 2008. С. 221-225.

6. Крогиус Ф.В. Ихтиологические работы на озере Имандра // Труды Мурман. биол. станции. 1926. Т. 2 , Вып. 1. С. 150-152.

7. Моисеенко Т.И., Даувальтер В.А., Лукин А.А., Кудрявцева Л.П., Ильяшук Б.П., Ильяшук Е.А., Сандимиров С.С., Каган Л.Я., Вандыш О.И., Шаров А.Н., Шарова Ю.Н., Королева И.М. (под ред. Моисеенко Т.И.) Антропогенные модификации экосистемы озера Имандра. М. Изд-во: Наука. 2002. 403 с.

8. П Паллон Л.О. Ихтиофауна горных озер района города Кировска // Материалы к изучению вод Кольского полуострова. 1940. Сб. 1. Рукопись. Апатиты. Фонды КНЦ РАН. 406 с.

9. Рыбы Мурманской области. Мурманск. Мурман. кн. изд-во. 1966. 336 с.

10. Соколов А.Г. Исследуя глубины. В Заполярье создан центр подготовки арктических водолазов и дайверов // Российская газета - Экономика Северо-Запада. № 159 (7917) 23.07.2019.

11. Терентьев П.М. Ихтиофауна горных озер в условиях разноуровневого загрязнения (на примере бассейна р. Большая Белая) // Глубокая переработка минеральных ресурсов. Сб. матер. IV школы молодых ученых и специалистов 6-8 ноября 2007 г. Апатиты. Изд-во: КНЦ РАН. 2008. С. 212-218.

12. Lukin A.A. The present State of an Arctic Charr (Salvelinus alpinus L.) population in Lake Imandra Subjected to Over Fishing // Journal of Ichthyology. 2013. V. 53. N. 10. P. 1-5. 